\title{
The persistence of the snow petrel (Pagodroma nivea) in Dronning Maud Land (Antarctica) for over 37,000 years
}

\author{
Göran Thor • Matthew Low
}

Received: 19 December 2009/Revised: 12 October 2010/Accepted: 14 October 2010/Published online: 31 October 2010 (C) The Author(s) 2010. This article is published with open access at Springerlink.com

\begin{abstract}
Two samples of snow petrel Pagodroma nivea mumiyo (solidified stomach oil) from Heimefrontfjella $\left(74^{\circ} 34^{\prime} 36^{\prime \prime} \mathrm{S}, 11^{\circ} 13^{\prime} 24^{\prime \prime} \mathrm{W}\right)$ in Dronning Maud Land, Antarctica, were radiocarbon dated at 37,400 $\pm 1,500$ and $3,120 \pm 70$ years old (dates are corrected for the 'reservoir effect'). The age of the older sample provides further evidence that snow petrel colonies have existed in the mountain peaks of Dronning Maud Land since before the last glacial maximum (approx. 20,000-16,000 years ago). This finding also pushes back the estimated timing of establishment of snow petrel breeding colonies in this part of the continent by several thousand years. The variation in the accumulation rates of these two samples (1.6 and $35.2 \mathrm{~mm}$ per millennium, respectively) supports previous observations that mumiyo accumulation rates are highly variable and probably relate to site-specific factors affecting accumulation and degradation of the oil. Studies that help us understand historical bird population distributions in continental Antarctica can significantly aid the development and refinement of models that explain glacial advancement and retreat, the relationship between sea ice and population viability and, perhaps, predict species responses to future climate shifts.
\end{abstract}

Keywords Antarctica $\cdot$ Radiocarbon dating $\cdot$ Seabird colonies $\cdot$ South Polar Skua $\cdot$ Nest occupancy

G. Thor $(\bowtie) \cdot$ M. Low

Department of Ecology, Swedish University of Agricultural

Sciences, PO Box 7044, 75007 Uppsala, Sweden

e-mail: goran.thor@ekol.slu.se

\section{Introduction}

The analysis of accumulated organic material around the nests of species exhibiting multi-generational site fidelity can yield important information on long-term population and environmental parameters (Houston and Nager 2009). In extreme cases, this build-up of material at bird nesting sites may represent thousands of years of occupancy, with stable-isotope analysis revealing colonisation patterns and changes in prey selection and foraging habitat over long periods of time (e.g. snow petrels Pagodroma niveaAinley et al. 2006; Adélie penguins Pygoscelis adeliaeEmslie et al. 2007; gyrfalcons Falco rusticolus-Burnham et al. 2009). For species that nest at high latitudes, such information is not only of interest to biologists but also to glaciologists, climatologists and oceanographers. This is because these birds can only nest on ice-free areas; thus, by using ${ }^{14} \mathrm{C}$-isotope analysis to date organic deposits, important information on the extent of ice cover during the late Pleistocene and Holocene epochs can be deduced (Ryan et al. 1992; Verkulich and Hiller 1994; Ainley et al. 2006; Thatje et al. 2008; Kiernan et al. 2009).

Breeding sites of the Antarctic snow petrel are a particular source of organic material for such analyses because of the bird's anti-predator defence behaviour, whereby it spits stomach oil at intruders. As a result of the cold and dry Antarctic environment, this oil solidifies around the entrance of snow petrel nest cavities, forming a stratified wax-like yellowish brown deposit known as 'mumiyo' (Warham 1977). Basal mumiyo layers (i.e. the first deposited and therefore the oldest) in many colonies have been found to be many thousands of years old (Verkulich and Hiller 1994; Ainley et al. 2006); the oldest deposits being found in (1) the Wohlthat Mountains (Untersee Oasis and Insel Range: approx. $71^{\circ} \mathrm{S}, 12^{\circ} \mathrm{E}$ ) in Dronning Maud 
Land, and radiocarbon dated to $32,600 \pm 3,020$ and $31,180 \pm 740$ years before the present $(\mathrm{BP})$ (reservoir effect-corrected values; Hiller et al. 1988, 1995) and (2) Svarthamaren $\left(71^{\circ} 53^{\prime} \mathrm{S}, 5^{\circ} 10^{\prime} \mathrm{E}\right)$ in central Dronning Maud Land $(32,520 \pm 1,700$ years $\mathrm{BP}$-reservoir-corrected values; Steele and Hiller 1997). The subfossil mumiyo deposits from these nunataks provide evidence that snow petrels colonised continental Antarctica before and during the last glacial maximum, probably utilising nearby polynyas in the Weddell Sea to find food (Thatje et al. 2008).

In 1991/92, the Swedish Antarctic Research Programme (SWEDARP) expedition to Dronning Maud Land performed a snow petrel survey in the Vestfjella $\left(73^{\circ} \mathrm{S}, 13^{\circ} \mathrm{W}\right)$ and Heimefrontfjella $\left(74^{\circ} \mathrm{S}, 11^{\circ} \mathrm{W}\right)$ (Johansson and Thor 2004). Vestfjella is a $135-\mathrm{km}$-long mountain range, up to $1,100-\mathrm{m}$ high and $120 \mathrm{~km}$ from the coast, situated parallel to the coastline in western Dronning Maud Land; Heimefrontfjella is a $135-\mathrm{km}$-long mountain range approximately $300 \mathrm{~km}$ from the coast and parallel to Vestfjella (Fig. 1). With the exception of some observational and count data (Ardus 1964; Bowra et al. 1966; Sømme 1977; Johansson and Thor 2004), little is known about these snow petrels except that the Heimefrontfjella colony is the largest far-inland breeding population of this species (Croxall et al. 1995). These nunataks are far from other well-studied snow petrel colonies in Dronning Maud Land (e.g. the Insel Range and Untersee Oasis of Hiller et al. (1988) is $>800 \mathrm{~km}$ away, Svarthamaren of Steele and Hiller (1997) is $>600 \mathrm{~km}$ away, and the Robertskollen nunataks of Ryan et al. (1992) are $>400 \mathrm{~km}$ away); thus, the timing of snow petrel colonisation events may have differed between these mountain ranges (e.g. during the period of ice expansion and retreat, potential nesting sites (Ryan et al. 1992) or polynya feeding areas (Thatje et al. 2008) may not have been uniformly available). In order to learn more about the past distribution of breeding snow petrels in Dronning Maud Land and the previous extent of the ice sheet associated with the Heimefrontfjella, one of the authors (GT) noted mumiyo deposits from snow petrel nesting sites and collected mumiyo deposits for radiocarbon dating.

\section{Methods}

\section{Study area}

Observation and collection of mumiyo deposits were made by GT in 1991/92. In Vestfjella, only the northernmost nunataks around the Swedish station Wasa $\left(73^{\circ} 02^{\prime} \mathrm{S}\right.$, $13^{\circ} 25^{\prime} \mathrm{W}$ ) were visited (i.e. Basen and Fossilryggen), which were occupied by 200-500 breeding pairs
(Johansson and Thor 2004). In Heimefrontfjella, the area around Scharffenbergbotnen in northern Sivorgfjella, where the Swedish field station Svea is located $\left(74^{\circ} 34^{\prime} \mathrm{S}\right.$, $\left.11^{\circ} 13^{\prime} \mathrm{W}\right)$, was surveyed; in addition, three high peaks were also surveyed (i.e. Engenhovet, Wrighthamaren and Paalnibba; for more details, see Johansson and Thor 2004). The number of snow petrels nesting in these areas was estimated to be 2,300-4,050 (Johansson and Thor 2004).

\section{Mumiyo collection and ${ }^{14} \mathrm{C}$ dating}

Mumiyo was frequently observed at snow petrel nests in the surveyed areas of Vestfjella and Heimefrontfjella; these were often mixed with rock fragments, feathers and guano. However, only in Heimfrontfjella were mumiyo deposits greater than a few centimetres thick observed. Three larger deposits that were located on bedrock were collected from two sites on the northern end of the Haldorsentoppen nunatak in Sivorgfjella, Heimefrontfjella. Site 1 (visited 4 January 1992) was located at the eastern end of the fourth small hill south of the Swedish field station Svea $(1,245 \mathrm{~m}$ above sea level; $74^{\circ} 34^{\prime} 36^{\prime \prime} \mathrm{S}, 11^{\circ} 13^{\prime} 24^{\prime \prime} \mathrm{W}$ ) at the base of a 20-m deep wind scoop approximately $25 \mathrm{~cm}$ above the snow level; site 2 (visited 30 January 1992) was located 200-300 $\mathrm{m}$ from site 1 , on exposed rock at the top of the second hill south of Svea. Two deposits were collected from site 1: C93/8003 (Swedish Museum of Natural History reference number), dimensions $15 \times 10 \times 6 \mathrm{~cm}$, weight $300 \mathrm{~g}$; C93/8002, dimensions $10 \times 10 \times 3 \mathrm{~cm}$, weight $200 \mathrm{~g}$; one deposit was collected from site 2: C93/ 8001 , dimensions $18.5 \times 18.5 \times 11 \mathrm{~cm}$, weight $1,500 \mathrm{~g}$.

The mumiyo samples were removed from the rock using a hammer and chisel; they were then wrapped in aluminium foil, sealed in a plastic bag and frozen at $-20^{\circ} \mathrm{C}$ for transport to Sweden. The specimens were kept frozen during shipment in early 1992 and are currently in cold storage at the Swedish University of Agricultural Sciences in Uppsala. The basal layer of the two largest samples (C93/8003 and C93/8001) was ${ }^{14} \mathrm{C}$ dated at the Laboratory for Isotope Geology at the Swedish Museum of Natural History (laboratory reference numbers for the two samples: ST14178 and ST14177, respectively). The conventional ${ }^{14} \mathrm{C}$ ages for each sample were then corrected for isotopic fractionation of ${ }^{\mathrm{TM} 13} \mathrm{C}$ [-29.0\% (sample 1) and to $-30.6 \%$ (sample 3)]. These ${ }^{\text {TM13 }} \mathrm{C}$ values from Heimefrontfjella were similar to other reports from Dronning Maud Land (Hiller et al. 1988; Ryan et al. 1992). Because of depletion of ${ }^{14} \mathrm{C}$ content in Antarctic waters, radiocarbon dating of mumiyo deposits tends to overestimate their age (the reservoir effect; Wand and Hiller 1987, Hiller et al. 1988); this has been estimated for this region of Antarctica at $850 \pm 300$ years (Hiller et al. 1988) and 1,300 \pm 200 years (Ryan et al. 1992). 
Fig. 1 The general location of the visited localities in the Vestfjella and the

Heimefrontfjella. Numbers refer to the surveyed localities. At Scharffenbergbotnen, they are 4 Steinnabben; 5 Boyensennuten; 6 Svea-Haldorsentoppen;

7 Haldorsentoppen-

Torsvikstoppen;

8 Torsvikstoppen-

Wrighthamaren;

9 Wrighthamaren-Engenhovet

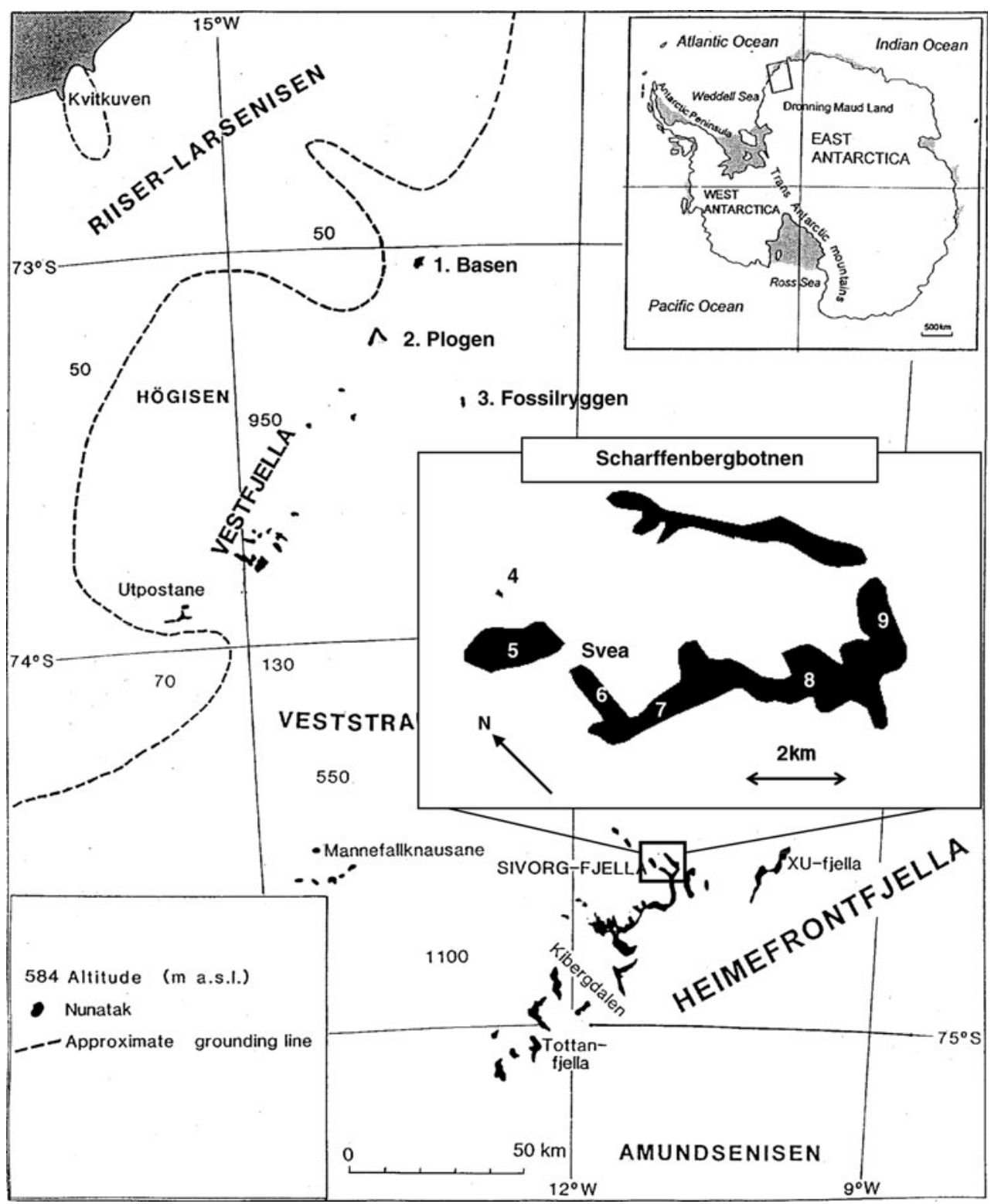

Thus, all reported radiocarbon dates in this study have been corrected by applying a conservative correction factor of $-1,300$ years (see also Hiller et al. 1995; Steele and Hiller 1997; Ainley et al. 2006).

\section{Results}

The basal layer of the 6-cm-thick sample (C93/8003) was radiocarbon dated to $37,400 \pm 1,500$ years (uncorrected estimate $=38,700$ years), while the basal layer of the 11-cm-thick sample (C93/8001) was radiocarbon dated to $3,120 \pm 70$ year $(4,420$ year uncorrected). This represents a growth in thickness of these two samples of 1.6 and $35.2 \mathrm{~mm}$ per millennium, respectively.

\section{Discussion}

The age of mumiyo sample C93/8003 (37,400 years) provides further evidence that snow petrel colonies existed in the mountain peaks of Dronning Maud Land during the last glacial period (70 to10 ka; Thatje et al. 2008). This finding also pushes back the estimated timing of establishment of snow petrel breeding colonies in this part of the continent by several thousand years (Hiller et al. 1988; Steele and Hiller 1997; Thatje et al. 2008) and shows that these pioneering colonies were widely distributed in Dronning Maud Land (Hiller et al. 1988, 1995; Steele and Hiller 1997; this study).

The largest mumiyo deposits in the study area were observed at Haldorsentoppen in Heimefrontfjella (where 
the samples were taken), up to a maximum 110-mm high. The sizes of these deposits were similar to those reported from the Untersee Oasis colony that has also been occupied for $>30,000$ years; the thickness of mumiyo in Hiller et al. (1988) ranged from 15 to $145 \mathrm{~mm}$ with the oldest deposit $(32,600$ years) being only $70-\mathrm{mm}$ thick $(60 \mathrm{~mm}$ in this study); in Steele and Hiller (1997), the 32,520 year BP sample was also only $70-\mathrm{mm}$ thick. Indeed, this range of thicknesses for mumiyo deposits is similar for other studies where the radiocarbon dates were much younger (Verkulich and Hiller 1994) and supports previous observations that accumulation rates for mumiyo based on radiocarbon age are highly variable (Verkulich and Hiller 1994; Hiller et al. 1995).

Although the thinner observed mumiyo deposits at Basen in the Vestfjella may indicate a younger occupancy time for this area, there are other factors that probably contribute to the size difference in the deposits between these two locations. Nest occupancy and predation risk are generally the factors considered to be most important in influencing the highly variable growth of mumiyo deposits (accumulation rates can span two orders of magnitude; e.g. Hiller et al. 1995), because they directly determine the amount of stomach oil ejected onto these sites (Warham 1977; Verkulich and Hiller 1994). However, liquefaction and degradation of the deposits may also play a role in limiting mumiyo growth-this would be expected to occur when temperatures rise above freezing. The Vestfjella differs from the Heimfrontfjella in that the rocks and air temperature in the nesting area are warmer during the breeding season because: (1) the Vestfjella is at a lower altitude and closer to the coast and (2) the bedrock at Basen is usually black (basalt and diabase with dolerite dikes), whereas in Heimefrontfjella, it is usually red or grey (weakly metamorphic red granite and grey augengneiss); dark rock can attain a surface temperature approximately $10^{\circ} \mathrm{C}$ higher than light-coloured gneiss of similar aspect (Engelskjøn 1986). Owing to the high intensity of solar radiation during the summer months in Dronning Maud Land, even during overcast conditions, as well as to the low albedo and the reflection of short-wave radiation from adjacent snow and ice surfaces, the surface temperatures of the nunataks can be considerably higher than air temperatures and must often be above freezing (Engelskjøn 1986; Jonsson 1988). Thus, any mumiyo degradation would be expected to be higher in Vestfjella than in Heimefrontfjella. It is also worth noting that for the sampling locations in the Heimefrontfjella, the slow-accumulating older sample was from a wind-exposed site at the bottom of a wind scoop. Future studies interested in factors affecting mumiyo accumulation should also consider the effect of wind and temperature on dispersal of the stomach oil and how this might affect mumiyo accumulation.
This study provides additional evidence for the understanding of historical bird population distributions in continental Antarctica. Together, similar studies can significantly aid the development and refinement of models that explain glacial advancement and retreat (Ryan et al. 1992), the relationship between sea ice and population viability (Thatje et al. 2008) and, perhaps, help predict species responses to future climate shifts.

Acknowledgments The Swedish Polar Research Secretariat funded both the visit by GT to Heimefrontfjella and Vestfjella in 1991/1992, and the ${ }^{14} \mathrm{C}$ analysis. Magnus Hedberg at the Laboratory for Isotope Geology at the Swedish Museum of Natural History kindly made the ${ }^{14} \mathrm{C}$ analysis.

Open Access This article is distributed under the terms of the Creative Commons Attribution Noncommercial License which permits any noncommercial use, distribution, and reproduction in any medium, provided the original author(s) and source are credited.

\section{References}

Ainley DG, Hobson KA, Crosta X, Rau GH, Wassenaar LI, Augustinus PC (2006) Holocene variation in the Antarctic coastal food web: linking $\delta \mathrm{D}$ and $\delta^{13} \mathrm{C}$ in snow petrel diet and marine sediments. Mar Ecol Prog Ser 306:31-40

Ardus DA (1964) Some observations at the Tottanfjella, Dronning Maud Land. Br Antarct Surv Bull 3:17-20

Bowra GT, Holdgate MW, Tilbrook PJ (1966) Biological investigations in Tottanfjella and central Heimefrontfjella. Br Antarc Surv Bull 9:63-70

Burnham KK, Burnham WA, Newton I (2009) Gyrfalcon Falco rusticolus post-glacial colonization and extreme long-term use of nest-sites in Greenland. Ibis 151:514-522

Croxall JP, Steele WK, McInnes SJ, Prince PA (1995) Breeding distribution of the snow petrel Pagodroma nivea. Mar Ornithol 23:69-99

Emslie SD, Coats L, Licht K (2007) A 45, 000 year old record of Adelie penguins and climate change in the Ross Sea, Antarctica. Geology 35:61-64

Engelskjøn T (1986) Botany of two Antarctic mountain ranges: Gjelsvikfjella and Mühlig-Hofmannfjella, Dronning Maud Land. I. General ecology and development of the Antarctic cold desert cryptogam formation. Polar Res 4:205-224

Hiller A, Wand U, Kämpf H, Stackebrandt W (1988) Occupation of the Antarctic continent by petrels during the past 35,000 years: inferences from a ${ }^{14} \mathrm{C}$ study of stomach oil deposits. Polar Biol 9:69-77

Hiller A, Hermichen WD, Wand U (1995) Radiocarbon-dated subfossil stomach oil deposits from petrel nesting sites: novel paleoenvironmental records from continental Antarctica. Radiocarbon 37:171-180

Houston D, Nager R (2009) Archaeology among the bird droppings: what does it tell us about raptor nest-site selection? Ibis 515:592-593

Johansson P, Thor G (2004) Observations on the birds of the Vestfjella and Heimefrontfjella, Dronning Maud Land, Antarctica, 1991/92 and 2001/02. Mar Ornithol 32:43-46

Jonsson S (1988) Observations on the physical geography and glacial history of the Vestfjella nunataks in western Dronning Maud Land, Antarctica. Naturgeografiska Institutionen, Stockholms Universitet, report STOU-NG 68. 57 pp 
Kiernan K, Gore DB, Fink D, White DA, McConnell A, Sigurdsson IA (2009) Deglaciation and weathering of Larsemann Hills, East Antarctica. Antarc Sci 21:373-382

Ryan PG, Steele WK, Siegfried WR, Vogel JC (1992) Radiocarbon dates of snow petrel regurgitations can reveal exposure periods for nunataks in Antarctica. S Afr J Sci 88:578-580

Sømme L (1977) Observations on the snow petrel (Pagodroma nivea) in Vestfjella, Dronning Maud Land. Norsk Polarinst Årbok 1976:285-292

Steele WK, Hiller A (1997) Radiocarbon dates of snow petrel (Pagodroma nivea) nest sites in central Dronning Maud Land, Antarctica. Polar Rec 33:29-38
Thatje S, Hillenbrand CD, Mackensen A, Larter R (2008) Life hung by a thread: endurance of Antarctic fauna in glacial periods. Ecology 89:682-692

Verkulich SR, Hiller A (1994) Holocene deglaciation of the Bunger Hills revealed by ${ }^{14} \mathrm{C}$ measurements on stomach oil deposits in snow petrel colonies. Antarc Sci 6:395-399

Wand U, Hiller A (1987) Kohlenstoff-14-Untersuchungen an Sturmvogelnistplatzen in der Antarktis. Beitr Vogelkd 33:129-140

Warham J (1977) The incidence, functions and ecological significance of petrel stomach oils. Proc New Zeal Ecol Soc 24:84-93 